\title{
Introduction to A Research Agenda for Corporations
}

This volume in the Research Agenda series explores a range of approaches to analysing the (global) corporation; the intent is to encourage researchers to adopt a more multi-disciplinary approach to studying and researching corporations. The research agenda proposed in this volume therefore has two distinct (although, of course, linked) elements: the first is a response to too much analysis of corporations being limited to (and by) its own academic or analytical silo. The approach adopted here is explicitly multi-dimensional and researchers are thereby encouraged to look beyond their own disciplines (or even closely allied disciplines) to seek out work on corporations that may further and differently illuminate puzzles and issues they are exploring. The second element is a call to establish a research agenda for corporations (and more widely business enterprises) in those disciplines that often merely assume or import uncritically an economistic account of business. This is not to argue that economics has necessarily got it wrong when it turns to the corporation or business enterprise, but rather to say that its analysis is only partial. Certainly, other disciplines and perspectives should not shun insights about corporations from economics, but rather should explore where they might add, modify and build in different analytical directions from economists' analyses. The discussion(s) in the following chapters will therefore suggest why an account of the corporation that engages with and combines a range of analytical approaches would likely lead to interesting avenues of analysis and research.

It is as well to be clear at the outset, however, that the intent of this book is to spur further research into corporations rather than necessarily offer a fully developed account of the political economy of the corporation itself or its future development, even if such an account might be inferred from what I have written. However, as will be clear from the final chapter, there is a clear strand of analysis that adopts a strong normative position, arguing that the contemporary corporation should be reformed. In this regard, a third element of the research agenda proposed herein is that research into the (global) corporation can (I would not be so presumptuous as to say 'should') be aimed at (re)thinking the political economy of the corporation itself. By doing so researchers could develop a political programme of reform that may gain some traction in the real world of economic relations of the business enterprise and 
specifically among those who seek to regulate and organise contemporary capitalism differently.

The need for the expansion of research into the corporation is further indicated by the exclusion of any extended discussion of the corporation as a subject of analytical interest in an otherwise relatively comprehensive recent guide to rethinking economics; firms and companies are mentioned in passing in a few chapters but nothing more (Rochon and Rossi 2017). As this suggests even though economic analyses of corporations may have some currency beyond the discipline, it remains an under-developed focus for those who wish to reform the discipline, reflecting a strange (albeit uneven) myopia in economics and political economy. Furthermore, it is nearly 30 years since Susan Strange argued that the study of international relations should (indeed must) include an account of the role of multinational corporations (Babic et al. 2017; Strange 1991), but there remains a noticeable lack of such attention. In both the study of (global) economics and politics, the corporation most often seems notable by its relative absence from the discussion. The following chapters will identify lots of interesting work, but often it seems to be at the margins rather than at the centre of focus of those (sub-) disciplines purporting to be concerned with the global system and its power relations.

It is important to stress that the discussions reviewed in the following chapters are not only relevant to those firms and enterprises formally constituted as corporations. Certainly some issues are legal questions that only directly concern corporations (firms that have been incorporated under various legislative arrangements in various jurisdictions), but others have much wider salience relating to issues that confront the analyses of non-corporate commercial/ economic organisations. Indeed, it is not the case that across all economies the corporation is the dominant domestic form of economic enterprise (Whitley 2010), even if this is much more so in the global realm. I also accept Isabelle Ferreras' point that the 'idea of the corporation has managed to eclipse the idea of the firm .... a Reductio as Corporationem [that] folds the firm into the corporation, despite the fact that the latter is merely the legal vehicle that structures capital investments' (Ferreras 2017: 5, 95). The corporate form (and a relatively exclusive discussion of it) obscures a range of other sorts of firms, an issue to which we return in the final chapter. That said, in this short book I often do conflate the firm and corporation, but nevertheless, I recognise that there is a need to balance the analysis of (globalised) corporate form(s) with the variable forms of collective economic organisation in national economies. Where an issue is of wider relevance, the questions raised will be relevant to partnerships, workers cooperatives and other ways in which collective economic activity can be organised. While this book is concerned with how we 
think about corporations' past and future, it seems to me that that in many areas the political economy of the corporation is not fundamentally different from that of other forms of business organisation.

Much of the available discussion of corporations has been undertaken in the various disciplines that find their home in management schools, but in critical social science(s) the corporation has been less readily explicitly included in analyses of the global system or of contemporary market society. Where non-management school social scientists have included corporations in their analysis this has largely (although not exclusively) been in the form of the recognition of (economic) power without responsibility, reflecting Ambrose Bierce's well-known definition from The Devil's Dictionary that a 'corporation' is an 'ingenious device for obtaining individual profit without individual responsibility' (Bierce 1911 [1958]: 25). Unfortunately, much of this critical analysis is relatively undifferentiated and therefore lacks a clear appreciation of the complexities of corporations' variable characters or practices. Indeed, as noted above, at times some critical social science seems to unreflexively import economic analyses of the corporation, which are then treated as viable depictions of a set of social relations such analysts wish to critique. This book is therefore intended to encourage the development of a more nuanced (or complex) understanding of corporations as political economic actors, building on existing research to suggest areas of potential further analytical development.

Establishing such a research agenda is necessary, as corporations have grown in importance in the (now) global political economy over the last one hundred years. At the beginning of the third decade of the new millennium, corporations with global reach control both digital platforms and informational resources that seem ever more central to everyday life and as such it should be no surprise that a new generation of students and activists is concerned about their power. However, the corporation (as an organised economic entity) has a long history encompassing international trading companies like the Dutch East India Company and multilateral clan- or family-based banking concerns such as those of the Rothschild family (and before them the Medici). That said, on the eve of the First World War, their economic activity remained mostly focused on domestic markets and economies. While there was international trading, this did not figure large in most enterprises' organisational considerations, but as the twentieth century progressed, so transport innovations, like cheap long-range communication technologies, and the standard-sized shipping container supported the growth of ever more complex and more widely geographically dispersed operations. 
It is now a commonplace to say a third of all international trade involves multinational corporations at one side or other of a transaction, and a further third of international trade involves transactions within global corporate networks themselves. The character of the organisation of much of this trade into global supply chains, where intermediate goods circulate between countries in international production networks, can have significant effects on how we understand and measure the global economy. For instance, this intra-corporate trade can lead to (quite extensive) double counting of global gross domestic product, as value-added is often counted in more than one country's data. It can also distort the reported global economic shares of some industrial sectors, again through the double counting of value-added in intermediate goods traded between sectors (UNCTAD 2013: 123-32). Furthermore, shifts in the global economy (as measured by gross domestic product and trade statistics) suggest that while economic activity (and specifically manufacturing) is moving away from the core, the home of major corporations (as indicated by headquarters and place of incorporation) remains in the developed states and reflects their domination of the global economic system (Kellogg 2015: 284-9). Therefore, transfer pricing and profit shifting have an important impact on perceptions of productivity of various locations in the corporate production network (given that productivity is measured as a value-added in monetary terms) and may be having a subtle but nevertheless significant impact on development and anti-poverty policies. Governments' desire to enrol their economies in global supply chains can skew priorities towards the needs of non-national enterprises as opposed to the needs of the local community (Fischer 2018: 205-13). Unsurprisingly, as a result, the disconnection of activity and the location(s) of corporate power centres underlie much of the discussion of how we understand power and influence in the global corporate political economy.

As domestic economies have become more and more open to international trade, so the role of the globalised corporation has become clearer and ever more important to understand. How corporations operate, how they interact with (and structure) markets and the manner in which they thereby influence our political economy are issues of some importance. However, elite managers (and to an extent shareholders) want to present the working of business as opaque and the subject of specialised knowledge. Moreover, invoking commercial confidentiality or technical economic analysis, those who run corporations and other major commercial enterprises have often sought to place themselves in the role not of agents, but rather as non-judgemental communicators of some (neutralised) commercial logic of business (Davies 2017: 230). This move is intended to depoliticise the conduct and practice of business, and as such has led to a common lack of critical political analytical engagement with global corporate practice(s). It is this lack of a political element that most 
often renders economic analysis of the corporation (and by extension business enterprises more generally) partial and requiring further development.

The difficulty of this (attempted) depoliticisation of business is that (as will become apparent below) the corporation is dependent on the state for its very existence; it is not some neutral/natural facet of human organisation, rather it has been constructed by the (initially European and American) state. What is perhaps most striking about the new millennium is the manner in which states' governments have sought to 'outsource governance' to these very products of political origin. This outsourcing of governance can be identified across three dimensions: firstly, states have sought to facilitate a political economic environment in which global supply chains can thrive (see Chapter 4). Secondly, states have recognised and empowered private governance of the corporate sphere establishing it as a form of legitimate governance (see Chapter 5). Finally, states have embraced a market governance logic that individualises the causes of inequality and attempts to inoculate global corporations from responsibility for growing global and national inequalities (an issue that underlies the whole of this volume) (Mayer and Phillips 2017). The key point is that developed states (and their governments) are not helpless patsies in the face of corporate power, but rather have been instrumental and cooperative in its establishment, development and expansion. For developing states, the story is somewhat different with their semi-dependence on corporate-controlled technology and control of access to corporate production networks placing them in a much weaker position.

So, the core purpose of this book is to encourage (more) researchers, social scientists and analysts to look behind the 'corporate veil' to find out what is actually going on, and ask how that might differ from at least some of the stories that get told about the corporate sphere, by both its supporters and its critics. Another key message of this book is that those attempting to understand our contemporary political economy cannot really move forward with their analysis without a nuanced appreciation of the role of corporations collectively and individually. Reflecting my established pedagogic approach, however, there is a touch of 'do as I say not as I do' about this book, for which I apologise. Like my ongoing undergraduate course on Economics for the Real World and a past course on corporations, one of my central contentions is that we can only really understand global corporations by looking at actual corporate behaviour by actual corporations. I accept I do not do this enough in this small book, but would point to Intan Suwandi's Value Chains: The New Economic Imperialism (Suwandi 2019) as an excellent recent example of the combination of general analysis and focused attention on particular corporations' actions/practices that I regard as the most fruitful way forward. Nevertheless, this volume is 
an attempt to lay out a wide-ranging research agenda, with the hope that colleagues will use these themes, issues and prompts as ways to develop their own more detailed, more particular research into corporations.

\section{The importance of corporate legal form(s)}

Although this book is not primarily focused on the legally constituted form of the corporation, nevertheless throughout the question of legality and regulation will be key to understanding potential research developments. Indeed, John Ruggie has suggested that the 'disjuncture between [the corporation's] economic reality and legal convention is the single most important contextual factor shaping the global institutional status of multinationals' (Ruggie 2018: 329). I will return to the issue of the corporation's absence from international law below, but Ruggie's emphasis on the need to understand the legal aspects of global corporations' constitution and activities is well put; too often, the legal is treated as epiphenomenal rather than constitutive of corporations' political economy. As Joel Bakan forcefully puts it, corporations

are legal constructs, created only through the operation of state law. They are rooted within and operate through domestic legal systems, tethered to and manifesting state sovereignty in every decision and action they take. There is no 'regulatory gap', no corporate space transcending state sovereignty, but only multiple corporate nationals operating in multiple nations - multinational corporations, but never truly transnational ones. (Bakan 2015: 298-9)

However, as we will see, considerable political capital is expended on both sides of the arguments about global corporate power to obscure this dependence. ${ }^{1}$ Before moving on, therefore, I will offer an initial description of the legal form of the corporation, as this will be often relevant to the agenda for future research into the development of the corporation in subsequent chapters.

Even though corporations as enterprises are organisations made up of groups of people, various social and internal institutions and capital (and other) assets mobilised towards a set of economic (and sometime extra-economic) ends, once incorporated they are treated as having a single personality for legal purposes. This pays clear organisational dividends within contract law for instance: the corporation is an effective unitary signatory to agreements and undertakings (which will be of some importance when we look at supply chains in Chapter 4). Immediately, this should draw our attention to corporations' crucial dependence on the state; not just in their legal incorporation, but more generally in the dependence on states upholding and maintaining a fully 
functioning form of contract law (Pistor 2014: 234). While there is no single and universal legal form for global corporations, and there are many other modes of corporate organisation, the central aspects of Anglo-Saxon legal form have become increasingly influential and widespread in the new millennium, especially as regards this question of legal personality and the associated need for this to be exercised under contract law.

For many business enterprises the desire (or need) to compete to raise capital in London or New York, and thus seek stock market listings in the UK or USA, is a significant incentive to adopt the specific legal arrangements including incorporation that comply with these countries' accounting and financial reporting requirements (Hansmann and Kraakman 2000). Compliance with such regulations has effectively exported a particular legal form to countries with differing legal traditions and practices. This partial convergence of legal forms has not necessarily been beneficial for the accountability of business; the increasing adoption of Anglo-Saxon modes of limited liability within the governance of subsidiaries has shielded companies and their shareholders from accountability across their international networks (Sahni 2005). This rests on a key element of the contemporary corporate legal form: the ability to hold stock (or own) other companies (Muchlinkski 2007: 35). Like 'real' individuals, in most jurisdictions corporations are legally able to hold shares in other corporations (or their own 'subsidiaries') allowing the company itself to benefit from the protection of limited liability (originally formulated to protect individuals from excessive risk, not corporations themselves), in its role as a holding company.

The assumption of legal personality through incorporation was (and remains, formally) a grant of authority by the state to carry out certain purposes for the public good. In the seventeenth century, when this first became widely used, these public purposes were defined by the state with relatively little public participation or deliberation. Nevertheless, they were framed as public (or at least public-regarding) interests, and therefore counter-posed to any existing unencumbered rights to private enrichment. Importantly, it offered in return for serving the public good (however defined) protection from the state's regulation of monopolies. This emphasises that legal personality is not an issue of the corporation having some (natural) similarity to human persons, but rather was a legal mechanism to solve a logistical problem of how groups of people acting together could formally and easily interact with other such groups to serve purposes regarded as socially useful by the state. However, (as a legal concept) it has taken on a 'life of its own' (Hess 2013: 329). An important shift in the political shape of incorporation has been a move from being conceived as the state's delegation of certain powers, to seeing it as a mode of protection 
from the state (Picciotto 2011: 113). As a result, often we are now told that corporations' forms and practices are not political but merely technical, opening up an interesting question for activists regarding how far such corporations actually do fulfil their side of any (now forgotten) bargain regarding the provision of public purpose(s) in exchange for privatised enrichment (Bakan 2004). Underlying much of the discussion that follows is the argument that the treatment of the corporation as a legally constituted individual, and the assumption that it necessarily contributes to economic well-being, needs to be carefully scrutinised and subjected to democratic deliberation if business and democracy are to be reconciled within a nascent global society.

Most corporations do not have the institutional longevity of many established sovereign states, but their enjoyment of legal personality (and the attendant rights of that personality) allows them to deploy considerably greater social power than the natural persons on whose rights these corporate rights are often modelled. To be clear, three distinct legal personalities are generally recognised in law:

- naturally existing people (that is, individuals in a particular jurisdiction);

- the state (in its role as collective location of sovereign and legal authority);

- the legally constituted corporation, a collective organisation recognised for the purposes of state-derived regulation as having a single legal personality (most importantly an identity that is separate from its members at any specific time).

This division is hardly natural, and while the division between (sovereign) political authority and individual subject (or later citizen) might be said to have emerged almost organically from the historical and legal requirements of nation state politics, the assumption of legal personhood by the corporation was a politically engineered legal innovation, as will be discussed in the next chapter.

As Steve Russell and Michael Gilbert have pointed out, 'Corporations have many advantages over natural persons: effective immortality, superior resources, and with globalisation, mobility on a scale available to few human beings' (Russell and Gilbert 2002: 45). The divergence between the legal protection available to all (legally constituted) people, and the different effective position of the various types of individuals claiming the protection of the law has been central to much critical discussion of modern corporations. For instance, Steve Tombs and David Whyte conclude that it

can act as a convenient shield for the key decision makers in the corporation. The corporation can effectively absorb the punishment, normally in the form of a fine, 
while its directors and senior managers are relatively rarely exposed to sanction. (Tombs and Whyte 2015: 98)

The legal person of the corporation allows the natural persons who actually take the decisions to evade (legal) responsibility for these decisions. We have allowed the corporation to become inhumane by ceding judgements about its practices to markets and the impact on share price (or 'shareholder value') (Mayer 2016: 70). Again, this is not a necessary development but rather is a political choice about economic organisation and its legal constitution.

When discussing corporations' legal character, the focus by definition remains at the level of the national jurisdiction in which such incorporation is achieved. However, as I have already noted, this book is as much concerned with the global corporation, not merely the various national forms and the varieties of corporate practices one can detect around the world. So, while certainly corporations remain outside the scope of international law (like other persons they are subjects only of national law), it is crucial to recognise that corporations' recourse to legalised personality is a relatively internationalised legal norm even if it remains a national jurisdictional matter. Nevertheless, despite the general acceptance of this norm, the corporation remains without a formal personality as regards international law, which in one sense renders international law 'unrealistic' in its account of the political terrain over which it rules (Nowrot 2006: 572; Ruggie 2018: 329). Of course, for critics, this legal lacuna is not a historical accident waiting to be resolved, but rather is a specific outcome of the global political economy of corporate capitalism.

While corporations may be influenced by international 'soft law', little regulation at the international level has been solidified into (hard) positive law to hold them firmly to account outside national jurisdictions (Muchlinkski 2007: 111); rather a form of 'networked governance' has been developed with the aid of international commercial lawyers working with (global) corporations. Rendered as depoliticised technical arrangements, networked governance brings together interested actors and organisations in the 'gap' between formalised international law, and national commercial law to establish a range of guidelines, agreements and protocols that reflect 'functional fragmentation' and the decentralised political realm of the global corporate realm (Picciotto 2011: 17-24). This builds on previous forms of lex mercatoria (the law of merchants) to ensure that the global political economy has a regulatory structure that enables and facilitates corporations' preference for stability and predictability but allows its subjects extensive influence over its form(s) and practice(s) and denies states any power to sanction corporate behaviour in the international realm. 
This has the advantage of offering corporations opportunities for organisational convergence with its posited associated efficiency benefits, but with few of the accountability costs of formal legislative development. This reflects the manner in which conservative and pro-business governments have reconfigured domestic laws to make them less constraining and more facilitative of corporate activity; moving away from protecting (however incompletely) public interests towards a focus more on enabling corporations and protecting their interests (Bakan 2015: 285). However, while the character of regulation has shifted and been refocused, this is not the same as any claimed deregulation of business. Rather, there has been a significant and ongoing process of re-regulation; this has not reduced regulatory instruments, as business interests often argue for, but has nevertheless reconfigured the proposed aims towards the interest(s) of corporate capital. In this, as Sol Picciotto puts it: 'regulation has become the tribute that corporate capitalism has been obliged to pay for continuing to maintain the private forms which allow its domination by a tiny elite, creaming off enormous wealth' (Picciotto 2017: 693). These moves, while advantageous to corporations, are also often an escape from effective and formal state regulation. As will be clear from subsequent chapters, much of the discussion of the political economy of the corporation revolves around how extensive this shift is in real terms and whether analysts see this as a problem or an opportunity for economic development.

Global legal variability does mean that multinational corporations are exposed to a significant legal tension however. They are constituted under the laws of their home country, and this will have some impact on their character and practices. At the same time, most countries require the local subsidiary operation of any corporation to be constituted under local (national) law, and as such frequently a global multinational corporation's legal form is highly diversified. This can lead to an attempt by governments of multinationals' home/ headquarters states to seek to extend their legal reach (the extraterritoriality of their regulatory focus) through the demands that local subsidiaries should be governed by the regulations of the home country even if these conflict with those of the subsidiary's host jurisdiction (Kobrin 2009: 189-90). Conversely, host states may also seek to hold multinationals accountable through national legal mechanisms; these may be in tension with the manner in which the corporation expects to manage its affairs in its headquarters (home) country. Additionally, where bilateral investment treaties (BITs) are in force, the host state may have ended up constricting its own ability to regulate as a way of 'encouraging' inwards investment, an increasingly fraught issue to which we will return when we discuss treaty arrangements for investor-state dispute settlement. 
While I would not necessarily self-identify as a proponent of legal institutionalism (see Deakin et al. 2017), my strong but not exclusive focus on the legal forms and structures that both support and constitute the (global) corporate sector means that there are distinct parallels with such an approach. The legal institutional approach emphasises that all firms (and thereby the corporations and business enterprises focused on herein) both are constituted in their specific form but require the law to operate - the law is unavoidable. The corporation is therefore a creature of the law, albeit with multiple (legal) parents; it is this question of how the corporation exists as a legal entity in the global political economy that in one sense lies at the heart of everything that follows. However, equally this does not mean that the law and legal analysis can tell us all we need to know about the global corporation.

\section{The utility of a multi-disciplinary approach to the (global) corporation}

One of the key reasons for adopting a multi-disciplinary approach to the analysis of (global) business enterprises is that as Julie Nelson has emphasised: 'business firms are not asocial machines operating in a vacuum, but are fully social entities with complex internal workings and which operate in deep interdependence with the ethical mores of the culture in which they participate' (Nelson 2016: 188). While for Nelson this underpins a call for a feminist approach to economics that foregrounds 'provisioning' and human flourishing (Nelson 2016: 196), here it is a useful prompt to recognise that an exclusively economic perspective on corporate practices will miss significant and important social elements that contribute to the understanding and explanation of such practices. There are many ways that such a multi-disciplinary approach might be characterised, but here I will refer to this as 'political economy' partly reflecting my long-term practice of drawing from a range of analytical traditions or perspectives (see May 2014: 17-32). This also builds on Homa Katouzian's now four decades old definition of political economy which included as a key element the idea that political economists always 'recognise the importance of other "non-economic", social facts, categories and theories, in their analyses of specific economic problems' (Katouzian 1980: 182). This is to say, in seeking to establish a research agenda centred on political economy, I will reach out to a range of disciplines, and in this case perhaps most immediately to the legal study of the corporation.

As I have already argued, the key reason for this immediate interaction with legal studies is that the corporation is essentially a legal construct - it is what 
law (and lawyers) make of it. To ignore these legal aspects of analysis is to adopt an analysis that lacks key ontological elements as regards the subject of analysis. This leads Jeroen Veldman and Hugh Willmott to conclude that when we see the corporation as a 'separate legal entity' (SLE) we see

a reified social construct formulated within a specific epistemological community whose concrete effects are mediated by processes of contestation over its status and significance ... Each historical stabilisation of the SLE has been conceived as a consequence of groups mobilising available resources that bestow and sustain material and symbolic advantage ... 'political contestation' and not 'community' is the key to the explication of the social ontology of the modern corporation. (Veldman and Willmott 2017: 1501)

The corporate form is maintained not by its social functionality ('community') as is often implied, but rather by the continued mobilisation of political interest. Moreover, thinking carefully about the social ontology of the corporation requires us to be alive to the contested place and character of the corporation as a distinct mode of social ordering; both reflecting sets of practices and organisational structures, as well as being something more than merely its material practices (Deakin 2017). Analysis of the corporation cannot be divorced from more ideational assumptions that are tied up with its legal form.

This volume reaches out across a range of disciplines and approaches to harvest insights and potential avenues for further research into the global corporate realm. This disciplinary inclusivity also reflects my long engagement with the work of Susan Strange, who even when not explicitly cited in subsequent chapters, remains perhaps the most influential background aspect to my political economy mind-set, albeit most recently in relation to work on the rule of law (May 2014: 17-32). Most famously, Strange was interested in the structures of power in which social relations took place; while immediate relational power issues were important, for Strange the context for such relations was the structure (or political economic context) in which these relations took place. For Strange, the political economy was patterned by four dimensions of structural power: security, production, finance and knowledge (Strange 1988). Strange saw no formal distinction between these structures; they are not ontologically separate spheres of activity. Indeed, her taxonomy of structures was not meant to identify hermetically sealed realms, quite the opposite: they are interpenetrated, and coexistent within a coterminous realm of political economy (Strange 1988: 24-8). They are an aid for identifying lacunae in political economic analyses rather than a closed account of the field itself, and are an invitation to a more permissive epistemology, one that does not necessarily promote one form of evidence, information or form of data above another. 
It is within the interactions of all four structures that specific 'bargains' between authority and market as mechanisms of control will be struck. In any particular case there is an (albeit temporary) settlement, produced by the mobilisation of power, between the use of political authority to pattern the distribution of benefits and the use of market mechanisms. This settlement is never absolute; there is always an element of both politics and markets but the bargain made in a particular instance will allocate one or other as the lead distributional device. To have structural power over production, security, finance or knowledge is to have the ability to set the 'rules of the game', the agenda of possibility ruling some things as options and others as nonsensical or even impossible. In the production structure, the forms and focus of productive activity are shaped and shifted by agendas set by those with structural power over productive activity and present such an agenda as the common sense of contemporary economic development. In the security structure, the identification of the character and requirements of a secure society are shaped and particular conceptions of insecurity (and thereby policy responses) defined by structural power over politic-social agenda setting. In the financial structure, the normalisation of specific credit creating and financialisation processes is (again) normalised; while in the knowledge structure (in Strange's work this is less developed analytically), issues ranging from the manner in which knowledge is controlled and owned to questions of what is acceptable as 'evidence' for policy-making are subject to forms of structural power. This led to Strange's abiding interest in the practices of business and how corporations (and other enterprises) shaped the (global) political economy (Stopford and Strange 1991). Global corporations are able to influence all four dimensions of the context of structural power (albeit unevenly and inconsistently), and as such, for Strange, were a necessary element of any discussion of the contemporary global system.

The intent of this approach is to avoid the silo thinking that has been identified as constricting analysis of corporations, and to establish a place for critical approaches (Baars and Spicer 2017: 4); this is clearly served by widening the remit of disciplines from which analytical substance is drawn. It is also a call to move beyond approaches that study corporations only to explain and/or understand their practices with a view to make them more effective, or only address the corporate form as a given social institution. As John Kay stridently argues:

Firms are social entities and cannot be divorced from their social context ... Reductionist accounts that see the firm as a nexus of contracts established in a competitive market, or as the expression of the will of the inspired leader, neglect the historically-determined pattern of relationships within any complex organisation 
which explain why some firms succeed - for a time - and others, often the same firms, fail. (Kay 2019: 12)

Multi-disciplinarity not only allows for analyses of how corporations work and are governed, but also allows for an interrogation of why they exist in the form that they do. This can be both historically defined enquiry (see next chapter) or a more political approach seeking to explore the range of social forces that maintain our (global) corporate economy (as explored in the rest of this volume).

This is not a novel suggestion: the most plausible and convincing analyses of how businesses (and corporations) engage with society have always been multi-disciplinary, even when their main analytical intent has been comparative (see, for instance, Moran 2009) or focused on the internationalisation of production (see, for instance, Dunning 1988). Moreover, others have also called for an expansion of multi-disciplinarity in the study of international business, albeit from a different starting point (Geppert and Dörrenbächer 2011). Certainly, as Mats Forsgren argues, one can identify a range of contending approaches to studying (multinational) corporations - he lists six approaches to characterising multinational firms: dominating, coordinating, knowing, designing, networking, or politicising - but, as he implies, the most fruitful analysis comes from combining these approaches in specific instances to understand how corporations operate in the global political economy (Forsgren 2013). For any specific issue, pragmatically different combinations of analysis may prove best suited to delivering particular insights but the key thing is not to see a mono-analytical approach as preferable. The complexity of the global corporate realm/sector requires analysis to reflect the range and diversity of issues that contribute both to corporate practices and decisions as well as the variety of social, economic and political responses that these practices may engender.

In this volume this comes together perhaps most obviously in the chapter on the global corporate supply chain which is an ideal terrain for multi-disciplinary analysis of corporate practices (see also Haufler 2018). This also reflects Nicola Phillips' argument that global production networks (supply chains and value chains) are the key terrain over which global political economy power is articulated, but also are a major site for the production of global inequalities. Within these production networks, asymmetries of social power, market power and political power shape the potentialities for development, the distribution of benefits (monetary and other) and the control of key assets from technology to material resources (Phillips 2017). Much of this will be explored in the chapter on global supply chains, but it is worth stressing, as Phillips does, that 
to understand the global corporation's political economy, the characteristic patterns of a 'global value chain world' cannot be ignored or downplayed. The best way to develop a compelling analysis of this 'world' is to adopt a pragmatic range of method/analysis. Multi-disciplinarity therefore underpins the analysis and suggestions for future research set out across all of the following chapters.

To be clear, a multi-disciplinary approach is not a complete rejection of mainstream economics based accounts of the corporation, but rather a reflection of the partial (incomplete) character of such accounts. Certainly some critics have argued that the discipline of economics has produced a managerial class that performs their economic function based on the de-socialised (formally modelled) economics they once learnt and by doing so reproduces an anti-social form of capitalism. Rather, I follow David Spencer in seeing 'bad management' of corporations as reflecting particular responses to the structural and practical aspects of capitalism itself, not as the result of the (often rather basic) education of managers by economics departments, and what they remember of it (Spencer 2020). Therefore, by adopting a multi-disciplinary approach, including legal analysis, sociology, geography, philosophical and other approaches the aim is to illuminate more, understand more and explain more about the particularities of the corporate political economy. A fully developed defence of multi-disciplinary practices' ontological and epistemological grounds is beyond the scope of this volume other than by demonstrating through the following chapters the pragmatic utility of this approach.

\section{What follows}

This book both maps out the range of issues that make up a multi-disciplinary study of the corporation, from national contexts to its global political economy, and suggests future avenues of fruitful research. Each chapter explores a set of themes that it strikes me are crucial to a fully rounded account of the political economy of the multifaceted global environment in which corporations operate, as well as prompting analysis of particular corporations, and concludes with some questions that seem to require further exploration. Chapter 2 sets the global political economy of the corporation in an historical context. The chapter develops a brief history of the corporate form and specifically the legal innovations that led to the normalisation of the act of incorporation. This history is related to the analysis of varieties of capitalism and the development of the global supply chain or production network, and includes some discussion of the shifting relations (in a general sense) between managers and workers. The chapter concludes with a consideration of the history of the cor- 
poration as a reflection of organisational processes highlighted by transaction cost economics. The key argument of the chapter is that it is impossible to fully understand the contemporary political economy of the corporation without placing it in an historical context even if in everyday research this remains more implied than formally and fully developed.

Chapter 3 asks: what is entailed in managing the corporation? This chapter focuses on law and planning, but also develops at some length the need to have a political understanding of the internal organisational dynamics of the business enterprise. This leads to a discussion of the classes involved, and that are to some extent in conflict within the corporation; the discussion ranges from workplace democracy to how we might understand the conduct of corporate managers. Perhaps unsurprisingly, this then leads to the first of two discussions of issues around the idea of corporate social responsibility. The chapter concludes by setting out why a focus on the internal management of the corporation matters, and by extension why any critical account of the corporate sector, as well as being aware of the structural issues, should be informed as to the real-world conduct of actual corporations.

After exploring a range of issues related to the internal management of the corporation, Chapter 4 examines the key terrain of the corporation's external governance function. Here I seek to demonstrate the utility of regarding the contemporary global corporation as an agent of global governance itself. To this end, we examine the global supply chain or production network, and the character of the political economic relations between core corporations and the small and medium sized enterprises that make up most of the ecology of these networks. Focusing attention on the governance of these networks foregrounds issues, such as legitimacy and democracy, that are usually absent from supply chain analysis. The chapter then moves to discuss the role that 'enrolment' plays in the supply chain in developing states' economic upgrading strategies, before examining the relations between these states and corporations as a site of corporate political economic power.

Having broached the issue of power, Chapter 5 examines the corporation's political agency across a number of dimensions. Starting from the relaxed attitude of neoliberals to corporations' quasi monopolies, the chapter then looks at issues related to political influence, before focusing in on the contested politics of investor-state dispute settlement and associated arbitration practices. The discussion then moves to the wider context of global governance of the corporation, including the United Nations Global Compact and the OECD guidelines for corporate practice. The question of taxing corporations draws many of the chapter's themes together, and then finally, the chapter (building 
on aspects of the class analysis from Chapter 4) looks at the political economy of the transnational capitalist class.

Chapter 6 asks whether reform of the global corporate sector is possible, returning to legal issues originally discussed in this first chapter. The chapter also looks at what reform of the global governance of corporations might entail, as well as developing further the account of corporate social responsibility (here as a mechanism of reform) commenced in Chapter 3, before linking that to the possibilities of the private regulation of corporate activity. The chapter concludes by examining the reform of the internal organisational logic of the corporation through an expanded (democratic) role for the workforce, and then asks whether the gig economy or 'platform capitalism' is the sort of reform that corporate managers prefer if left to their own devices.

All of this is intended to suggest avenues of further research, interesting interactions between research foci too often kept apart by disciplinary boundaries, and to criticise the idea that corporate management is best treated as a rational response to cost control. I do not offer a well-rounded coherent account of the corporation; rather, I hope the reader, suitably intrigued by connections that emerge across the book, will find this a useful prompt for further developing their own research.

\section{Note}

1. Here I should note that, like Bakan but unlike many books and articles on globally active corporations, I will not be using the term 'transnational corporation(s)'; like Bakan, to my mind this implies a level of disconnection from the world of international political economy that few if any corporations achieve. In this book I therefore use the term global corporations to capture the scope of their operations without seeking to claim they are disconnected from national jurisdictions, a claim which, as I hope this book will demonstrate, misses the corporations' continuing and crucial reliance on the intersection of national legal jurisdictions. 
Christopher May - 9781788977531 